\title{
A CASE OF DERMO-FIBRO-LIPOMA OF THE CONJUNCTIVA ASSOCIATED WITH OTHER CONGENITAL ABNORMALITIES
}

BY

\author{
H. B. Stallard and P. P. Martin \\ LONDON
}

WE report this case of congenital dermo-fibro-lipoma of the conjunctiva associated with other abnormalities, in the belief that it is of unusual interest.

In January, 1930, a boy, aged $3 \frac{1}{2}$ years, attended the Moorfields Eye Hospital. His mother had brought him on account of a swelling on the outer part of the right eye which she had observed since his birth. He had been troubled by recurrent attacks of inflammation in this eye, in the nature of a mild conjunctivitis.

He was the first child and except for a prolonged labour the birth was normal. When $3 \frac{1}{2}$ months pregnant, the mother had two teeth extracted from the right lower jaw. She remarked that at birth her son had a distinct cavity in the right lower jaw at a similar site to her extractions, and subsequently she noticed that his last tooth to erupt was also at this area. There was no family history of a congenital anomaly of the parents on either side.

Fig. 1 is a drawing of the right eye, and it shows the shape, size, and position of the swelling, which extended from the upper to the lower fornix, nearly to the outer canthus, and to within $4 \mathrm{~mm}$. of the limbus, except at a position corresponding to 8 o'clock where a tongue-like process reached the limbal margin.

The surface was smooth and faintly lobulated; the colour, a pinkish yellow; and the consistence, soft-elastic. Projecting from the surface were four hairs, and it is thought that these were a factor in the recurrent attacks of mild conjunctivitis. The swelling was confined to the bulbar conjunctiva and subconjunctival tissues, and it could be moved over the globe. There was no clinical evidence of an association with an orbital neoplasm. The inner canthus was wider on this side than on the left and the caruncle was present. There was also a right convergent strabismus the cause of which proved to be mechanical, for it disappeared after removal of the tumour. The child was intelligent and appeared to have good visual acuity in each eye and presented no other ocular abnormality.

A general examination revealed certain other congenital defects.

Fig. 2 shows a marked facial asymmetry, the face being flattened over the right lower jaw; and it seemed on palpation that the 


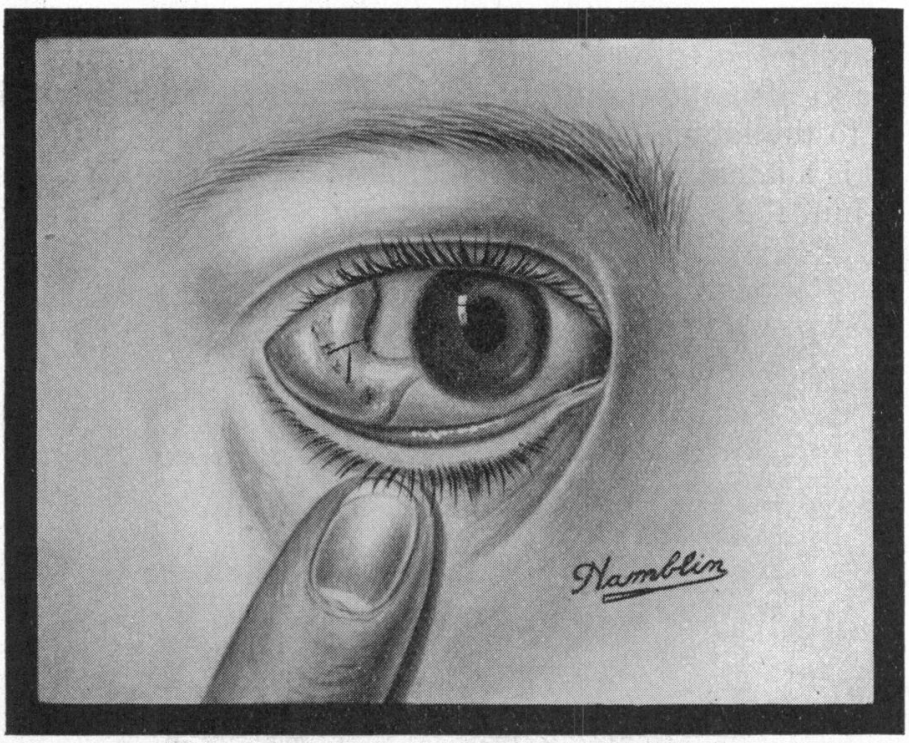

FIG. 1. 
junction of the body and the ramus of the mandible on the right side was represented by a gradual curve instead of an angle. The photograph also shows an accessory auricle situated immediately anterior to the lobule of the right ear.

Fig. 3 is a lateral view of the right auricle. The auricle was well formed but the external auditory meatus was imperforate and

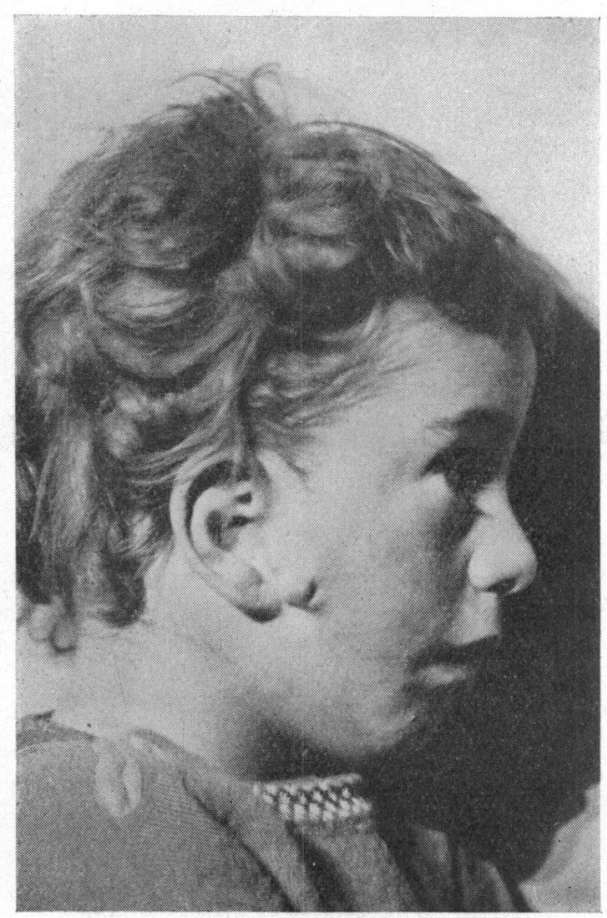

FIG. 3.

covered over by skin which extends from the tragus to the concha. Hearing, on the right side, was only slightly impaired on testing with a watch and tuning fork.

The teeth and remainder of the body presented no abnormality.

Radiographs of the skull, and particularly the mandible and teeth, were taken at University College Hospital, and Dr. R. W. A. Salmond was good enough to report on these.

\section{Report of X-Ray Examination}

"There is marked asymmetry of the lower jaws, that on the right side being smaller and less developed than the left. As regards the teeth, all the temporary ones in both the upper and 
lower jaws are erupted and normal in number. None of the permanent ones have erupted in either jaw but the lower 1st molars are on the point of breaking through."

The boy was admitted to the Moorfields Eye Hospital and the swelling excised and submitted to histological examination.

\section{Pathological Report}

Fig. 4 is a microphotograph of a piece of the section.

The surface of the swelling is covered by stratified squamous epithelium. There is no superficial keratinization. Beneath the

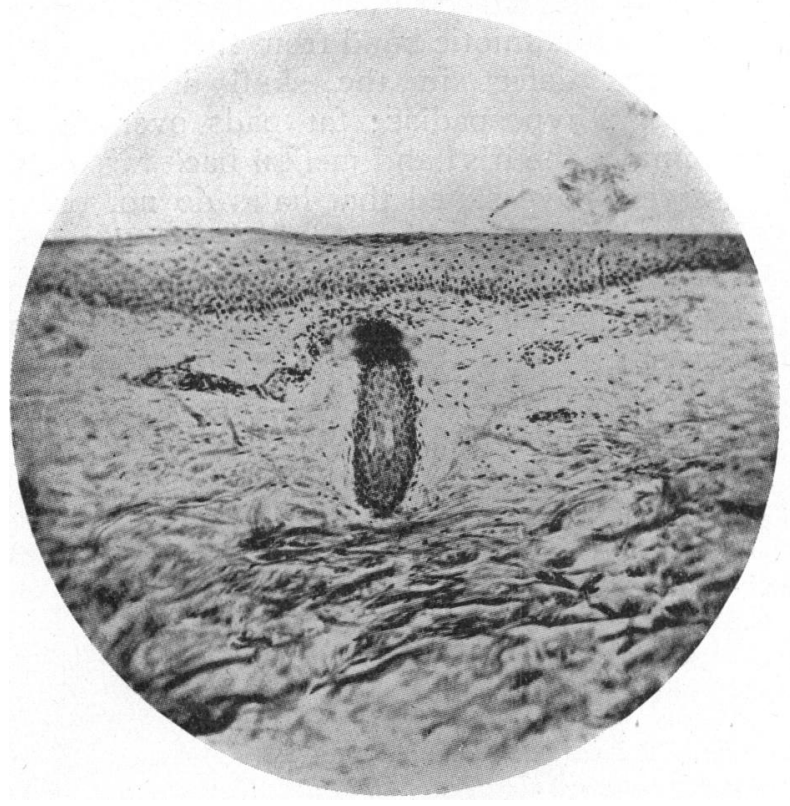

FIG. 4.

Microphotograph which shows from above downwards :Stratified squamous epithelium.

Sub-epithelial connective tissue.

Hair follicle.

Blood vessels.

Bundles of fibrous tissue and unstriped muscle fibres.

The lobules of fat are not shown in this microphotograph.

epithelium there is a thin layer of connective tissue containing hair follicles and capillaries, and deep to this there is a mass of fibrous tissue and unstriped muscle, the fibres of which are arranged in irregular interlacing bundles. This fibro-muscular 
tissue is denser and thicker in the centre of the tumour than at the periphery and it covers a mass of fat which is divided up into lobules of various shapes and sizes by strands and trabeculae which pass into it from the overlying fibrous tissue. Hair follicles and blood vessels are also present in this mass of fibro-muscular tissue.

Pathological Diagnosis.-Dermo-fibro-lipoma of conjunctiva. The right convergent strabismus disappeared and recovery was uneventful. The boy remains in good health. It is proposed to deal with the other congenital abnormalities at a later date.

In the literature, cases of dermo-lipoma are reported associated with other congenital defects. Of particular interest is that case described by Lamb and Hardy in which the following anomalies were also present ; an amniotic band from the outer canthus to the cheek; an osseous defect in the skull at the pterion; an undescended testis; hypospadias; fat pads over the symphysis pubis; a coloboma of the iris ; and mental backwardness.

Several observers have stated that hairs do not occur in these tumours before puberty, but this was not so in the case we have reported above.

We express our thanks to Sir John Parsons for permission to publish this case.

\section{LITERATURE}

Alt.-A mer. Jl. of Ophthal., p. 39, 1889.

Bögel.-Arch. f. Ophthal., Vol. XXXII, p. 129, 1886.

Derby.-Trans. Amer. Ophthal. Soc., Vol. II, p. 430, 1878.

Fehr.-Zentralb. f. prak. Augenheilk., p. 202, 1908.

Gunn, Marcus.-Ophthal. Rev., p. 261, 1889.

Hirschberg and Birnbacher.-Zentralb. f. prak. Augenheilk., Vol. VII, p. $295,1883$.

Kranka.-Ann. d'Ocul., Vol. XXXI, p. 105, 1854.

Lagrange.-Tumeurs de l'Oeil. Vol. I, Paris, 1901.

Lamb and Hardy.-Amer. Jl. of Ophthal., Vol. XXXIII, p. 321, 1916.

Nobbe.-Arch.f. Ophthal., Vol. XLIV, p. 334, 1897.

Parsons.-Pathology of the Eye. Vol. I, p. 135.

Reuss.-Zentralb. f. prak. Augenheilk., Vol. XV, p. 124, 1891.

Rieke.-Arch. $f$. Augenheilk., Vol. XXII, p. 239, 1891.

Rochat.-Nederlandsch Tjdschr. v. Geneesk., Bd. I, p. 307..

Rogman.-Ann. d'Ocul., Vol. CXIX, p. 81, 1898. 